\title{
New Method of Depositing the Nanostructured Amorphous Carbon for Carbon Based Solar Cell Applications
}

\author{
A. N. Fadzilah, ${ }^{1}$ K. Dayana, ${ }^{1}$ and M. Rusop $^{2}$ \\ ${ }^{1}$ NANO-ElecTronic Centre, Faculty of Electrical Engineering, Universiti Teknologi Mara (UiTM), 40450 Shah Alam, Selangor, Malaysia \\ ${ }^{2}$ NANO-SciTech Centre, Faculty of Electrical Engineering, Universiti Teknologi Mara (UiTM), 40450 Shah Alam, Selangor, Malaysia \\ Correspondence should be addressed to A. N. Fadzilah; nurfadzilahahmad@yahoo.com
}

Received 7 March 2013; Revised 25 April 2013; Accepted 25 April 2013

Academic Editor: Vincenzo Augugliaro

Copyright (c) 2013 A. N. Fadzilah et al. This is an open access article distributed under the Creative Commons Attribution License, which permits unrestricted use, distribution, and reproduction in any medium, provided the original work is properly cited.

\begin{abstract}
Nanostructured amorphous carbon (a-C) solar cells were successfully deposited via a self-designed aerosol-assisted chemical vapor deposition (AACVD). The fabricated solar cell with the configuration of Au/p-C/n-Si/Au achieved efficiency $(\eta)$ of $1.72 \times 10^{-4} \%$ for device deposited at $500^{\circ} \mathrm{C}, 1.24 \times 10^{-4} \%$ for $450^{\circ} \mathrm{C}$, and $0.03 \times 10^{-4} \%$ for $400^{\circ} \mathrm{C}$. Photoresponse characteristic was highlighted under illumination ( $\mathrm{AM} 1.5$ illuminations: $100 \mathrm{~mW} / \mathrm{cm}^{2}, 25^{\circ} \mathrm{C}$ ), where conductivity increased when the sample was being hit by light. Transmittance spectrum exhibits a large transmittance value $(>85 \%)$ and absorption coefficient value of $10^{4} \mathrm{~cm}^{-1}$ at the visible range from 390 to $790 \mathrm{~nm}$. The nanostructured a-C thin film deposited at higher temperature possesses lower transmittance due to higher absorption as a result of the higher content of $\mathrm{sp}^{2}$-bonded carbon atoms. From Tauc's plot, optical band gap $\left(E_{g}\right)$ was determined, and $E_{g}$ decreased as deposition temperature increased $(1.2 \mathrm{eV}, 1.0 \mathrm{eV}, 0.7 \mathrm{eV})$. On the other hand, FESEM images exhibited a nanostructured sized a-C with the particle size less than $100 \mathrm{~nm}$. To the best of our knowledge, the presence of nanostructured particle of a-C by a self-prepared AACVD has not frequently been reported.
\end{abstract}

\section{Introduction}

Amorphous carbon (a-C) thin films were extensively studied in the last two decades due to many superior properties such as high mechanical hardness, chemical inertness, and optical transparency [1]. This structure based on carbon materials has attracted a great interest for the potential applications in optoelectronic devices especially in the development of the photovoltaic solar cell, due to the fact that the cost in heterojunction solar cell using silicon is much higher to meet the daily life expectations. Nanostructured a-C is a potential candidate for the solar cell application due to its semiconducting nature which is able to accept dopants [2], wide band gap from $0.0 \mathrm{eV}$ to $5.5 \mathrm{eV}$ [3], and tunable band gap by adjusting the $\mathrm{sp}^{2}$ and $\mathrm{sp}^{3}$ of carbon bonding ratio [4]. On the other hand, nanostructured a-C have the advantage over the conventional silicon in photovoltaic due the usage of silicon at a long period of time that leads to the degradation process which limits its lifetime and stability [5].

Prior to the interest in nanostructured a-C utilization for wide range of applications, several techniques were developed to synthesize the nanostructured a-C including pulsed laser deposition (PLD) method [3], pulsed filtered cathodic method [6], and filtered cathodic vacuum arc method [7] which are generally expensive because they involve the use of sophisticated reactors and vacuum systems. On the other hand, the chemical vapor deposition (CVD) technique which involves homogenous and heterogenous chemical reaction of gaseous reactants was also being utilized in the fabrication of nanostructured a-C. However, several limitations has been experienced by researchers in utilizing the CVD method in terms of selection and delivery of multicomponent products, the lack of proper volatile precursor, and the difficulty in controlling the stoichiometry of the deposition [8]. In pursuit of producing high electrical conductivity of nanostructured $\mathrm{a}-\mathrm{C}$, the conventional CVD process was self-modified into aerosol-assisted CVD (AACVD), where this method uses the aerosol droplets to transport the precursor, with the aid of carrier gas (inert gas).

AACVD method was widely used in the fabrication by other researchers, such as to fabricate the $\mathrm{ZnO}[9]$ and $\mathrm{InMe}_{3}$ [10]. In addition, Salaün et al. [11] have shown the successful 
deposition of nanoparticles using AACVD technique, where the incorporation of nanoparticles in thin film fabrication is important due to their functional properties in electronics, sensors, glass, catalysis, and semiconducting applications. Thus, by considering the successful fabrication of other materials using the low-cost aerosol-assisted method, this technique was implied in the preparation of the semiconducting nanostructured a-C thin film for the environmentally safe carbon-based thin film for solar cell application. Considering the advantages of AACVD as the deposition method, this technique was implied in the preparation of the semiconducting nanostructured $\mathrm{a}-\mathrm{C}$ thin film for the environmentally safe carbon-based solar cell application. The electrical, optical, and solar cell performances were discussed in this paper.

\section{Methods}

Camphor oil $\left(\mathrm{C}_{10} \mathrm{H}_{16} \mathrm{O}\right)$ was chosen as the precursor due to its advantageous over any other precursor, as the single camphor molecule contains $9 \mathrm{sp}^{3}$ carbon atoms [12]. Corning glass (thickness: $1 \mathrm{~mm}$ ) and $\mathrm{n}-\mathrm{Si}$ (100) (thickness $525 \pm 25 \mu \mathrm{m}$, resistivity $1-10 \Omega \mathrm{cm}$ ) were used as the substrates. Glass substrates have been cleaned in acetone $\left(\mathrm{C}_{3} \mathrm{H}_{6} \mathrm{O}\right)$ followed by methanol $\left(\mathrm{CH}_{3} \mathrm{OH}\right)$ for $10 \mathrm{~min}$, respectively, using an ultrasonic cleaner (Power Sonic 405) to eliminate contaminations. In the case of $\mathrm{n}$-Si substrate cleaning, the cleaning step was further continued with the diluted hydrofluoric acid which plays an important role in removing the resistive element of the substrate. Finally the substrate was blown with nitrogen gas $\left(\mathrm{N}_{2}\right)$.

The depositions of nanostructured a-C thin films were carried out using the combination of aerosol-assisted system and CVD with two furnace systems. Camphor oil was heated at the aerosol-assisted system in a close environment (to ensure the desired temperature) at $180^{\circ} \mathrm{C}$ to make certain of the transformation of the camphor oil in liquid phase into vapours. A double furnace setup of thermal CVD was connected next to the aerosol-assisted setup, where the deposition took place. Argon gas (30 bubbles/min) was selected as the carrier gas, and the quartz tube was kept inside a horizontal tubular furnace. AACVD process includes the atomization of a liquid precursor solution (camphor oil) into fine submicrometer-sized aerosol droplets that distribute throughout the gaseous medium in the CVD with the aid of Ar gas as the carrier gas. Temperature of the furnace was elevated from room temperature to desired deposition temperature under argon atmosphere. Gold $(\mathrm{Au})$ which is a known conductor material was sputtered on the top and bottom of nanostructured a-C thin films by using the sputter coater system. The nanostructured a-C thin films was characterized by PerkinElmer Lambda- $60 \mathrm{~mm} \mathrm{PbS}$ module integrating sphere relative specular reflectance ACCY- 6DE spectroscope for optical propertie, Bukoh Keiki CEP2000 solar simulator system for electrical properties, and JEOL JSM-7600F field emission scanning electron microscope (FESEM) to determine the particle size.

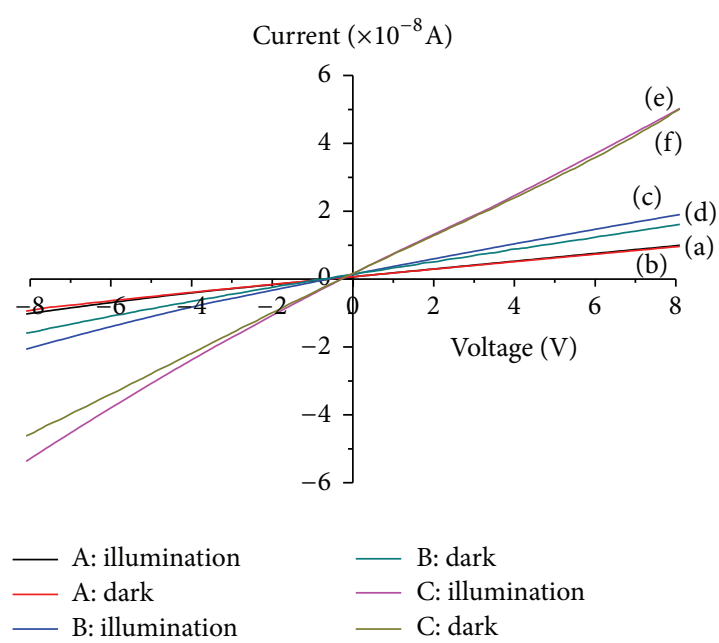

FIGURE 1: $I-V$ characteristics of the nanostructured a-C thin films in dark and under illumination.

\section{Results and Discussion}

Nanostructured amorphous carbon (a-C) films were deposited on $\mathrm{n}-\mathrm{Si}$ and glass substrate at 3 different deposition temperatures, $400^{\circ} \mathrm{C}$ (sample $\mathrm{A}$ ), $450^{\circ} \mathrm{C}$ (sample $\mathrm{B}$ ), and $500^{\circ} \mathrm{C}$ (sample $\mathrm{C}$ ). To study the electrical properties of nanostructured a-C thin films, the $I-V$ measurement was carried out using Bukoh Keiki CEP2000 solar simulator system in the range from -8 to $8 \mathrm{~V}$ to obtain the $I-V$ graph as in Figure 1 , and the value of resistivity $(\rho)$ and conductivity $(\sigma)$ was calculated from the value of resistance using,

$$
\begin{gathered}
\rho=\left(\frac{V}{I}\right)\left(\frac{w t}{L}\right), \\
\sigma=\frac{1}{\rho},
\end{gathered}
$$

where $\rho$ is the resistivity, $\sigma$ is the conductivity, $w$ is the width of electrodes, $t$ is the thickness of nanostructured a-C thin film, and $L$ is the distance between the electrodes. As shown in Figure 1, the linear graph shifted upward as deposition temperature increased, showing low electrical resistance of sample deposited at higher temperature. However, all the samples with low-resistive linear current voltage indicate good ohmic contact. These $I-V$ measurements prove that the graphitic behavior within the nanostructured a-C is able to serve as conductive channels for the transport of electrons [13]. The electrical conductivity, $\sigma$, was plotted as in Figure 2, and it was observed that the sample with sharp slope (sample C) has the highest $\sigma$. The measurement was done in dark and under illumination condition AM 1.5 illumination $\left(100 \mathrm{~mW} / \mathrm{cm}^{2}\right.$, $25^{\circ} \mathrm{C}$ ). The thickness of the thin films was evaluated from the DEKTAK VEECO 150 surface profiler, and it was noted that as deposition temperature increased the thickness also increased (42, 54 and $67 \mathrm{~nm})$.

Without light irradiation, the in dark conductivity $\left(\sigma_{d}\right)$ value starts from $1.04557 \times 10^{-4} \mathrm{Scm}^{-1}$ for sample A, increases gradually to $1.35543 \times 10^{-4} \mathrm{Scm}^{-1}$ at sample $\mathrm{B}$, and increases 


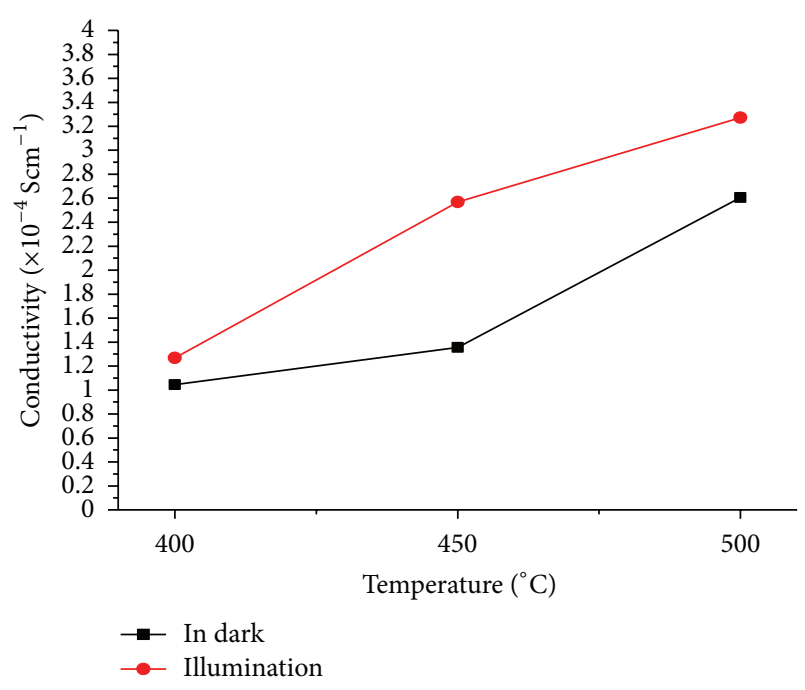

FIgURE 2: Electrical conductivity of the nanostructured a-C thin films in dark and under illumination.

sharply at sample $\mathrm{C}\left(2.60586 \times 10^{-4} \mathrm{Scm}^{-1}\right)$. The conductivity value is higher in comparison with the reported value by Panwar et al. [7] and Dwivedi et al. [14] and is similar to that reported by Alibart et al. [15] and Ben Karoui et al. [16]. Even though the conductivity value was not extremely high, the value was comparable with the conductivity reported for the solar cell application. To explain the conductivity trend, carrier concentration and carrier mobility play the significant role in determining the value of electrical conductivity [15]. Thus it is reported that when thickness increases, the carrier concentration and carrier mobility will increase along [17], and this explains the high conductivity of sample deposited at higher temperature since the thickness increased and can be seen by naked eyes. Other than that, nanostructured a-C conductivity is also attributed by the presence of $\pi^{*}\left(\mathrm{sp}^{2}\right.$ graphitic bonding) and $\sigma^{*}\left(\mathrm{sp}^{2}\right.$ and $\mathrm{sp}^{3}$ diamond bonding). As temperature increases the intensity of $\pi^{*}$ region increases, specifying the promotion of $\mathrm{sp}^{2}$ bonding due to the increase in graphitic order [18].

Under AM 1.5 illumination $\left(100 \mathrm{~mW} / \mathrm{cm}^{2}, 25^{\circ} \mathrm{C}\right)$, samples A-C observed the same conductivity trend, but with higher value. The under illumination conductivity $\left(\sigma_{i}\right)$ value starts from $1.26746 \times 10^{-4} \mathrm{Scm}^{-1}$ for sample A increases gradually to $2.56846 \times 10^{-4} \mathrm{Scm}^{-1}$ at sample B, and increases sharply at sample $\mathrm{C}\left(3.27256 \times 10^{-4} \mathrm{Scm}^{-1}\right)$. Shifting upwards condition of $\sigma_{i}$ to $\sigma_{d}$ symbolize the photoresponse characteristic of nanostructured a-C [12]. As one of the potential material for solar cell application, the photoresponse characteristic is highly observed. When being illuminated, the electron-hole pairs that are separated by the electric field between the electrodes from the light absorption will generate the current flow [19]. Current flow is the result of the photoexcited carriers drift before recombination.

Optical properties was investigated by a PerkinElmer Lambda- $60 \mathrm{~mm} \mathrm{PbS}$ module integrating sphere relative specular reflectance ACCY- 6DE spectroscope measurement for the samples deposited on the glass substrates. The highest

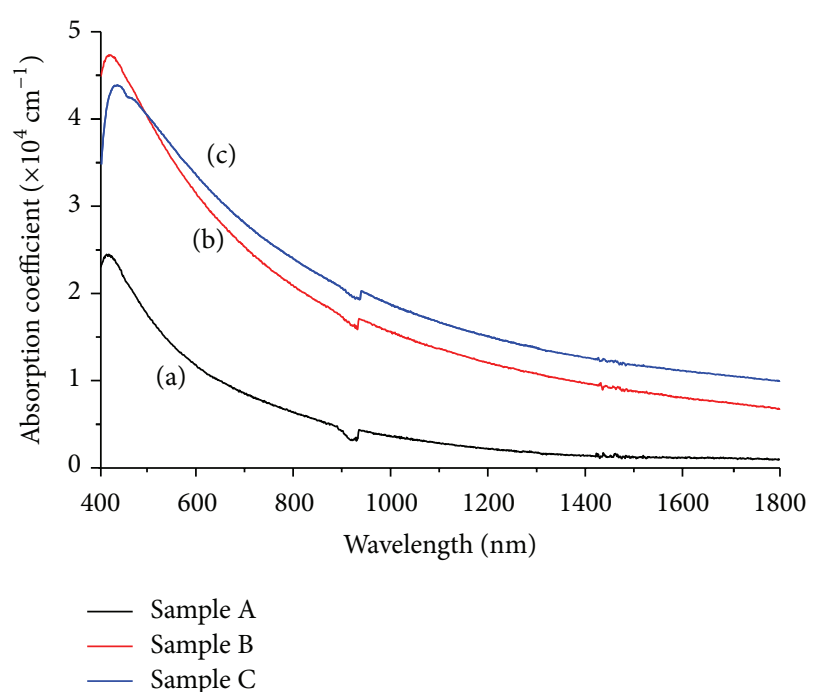

FIGURE 3: Absorption coefficient spectrum of the nanostructured aC thin films.

transmittance was indicated at sample A followed by B and C. Considering that by naked eyes sample $\mathrm{C}$ is darkest and thickest compared to sample A and B, the UV-vis-NIR spectroscope measurement confirmed the condition. At the visible range from 390 to $790 \mathrm{~nm}$ (from 1.56 to $3.18 \mathrm{eV}$ ), transmittance for sample A is above $95 \%$, sample B 85-95\%, and sample C increase from $60 \%$ to $90 \%$. Han et al. [20] in the reports on solar cell discussed the suitability of having high transmittance $(>85 \%)$ at visible range since the reflection at the surface was suppressed. The transmittance obtained is considered high compared to the other reported value for solar cell application, aluminum-doped zinc oxide ( $\mathrm{ZnO}: \mathrm{Al})$ [21], and Vanadium pentoxide $\left(\mathrm{V}_{2} \mathrm{O}_{5}\right) / \mathrm{Ag} / \mathrm{V}_{2} \mathrm{O}_{5}$ [22] .

The absorption coefficient $(\alpha)$ was calculated by the optical transmittance spectra of the film and the film thickness data, which indicates the measurement on how far the light with a specific wavelength or energy can penetrate into the thin film before being absorbed by that film. The $\alpha$ of nanostructured a-C thin films could be calculated by Lambert's law using

$$
\alpha=\frac{1}{t} \ln \left(\frac{1}{T}\right)
$$

where $t$ is the thickness and $T$ is the transmittance of the film. Figure 3 shows the variation of the absorption coefficient as a function of photon energy. As shown in Figure 3, $\alpha$ value is approximately $\sim 10^{4} \mathrm{~cm}^{-1}$ and in the range reported by others $[23,24]$. The highest value of $\alpha$ in sample $C$ is due to the narrow optical band gap from Tauc plot [25]. The optical band gap is the measure of the gap between the extended state in the valence band and the conduction band. Highest band gap was noted at sample A $(1.2 \mathrm{eV})$ followed by sample B $(1.0 \mathrm{eV})$, and the smallest was sample $\mathrm{C}(0.7 \mathrm{eV})$. The largest optical band gap is correlated with the amount of $\mathrm{sp}^{3}$ carbon bonding inside the nanostructured $\mathrm{a}-\mathrm{C}$ and supports the electrical conductivity discussed above. 


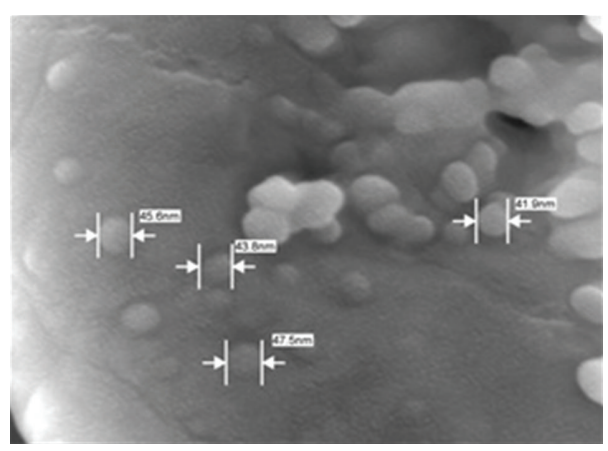

(a) Sample A

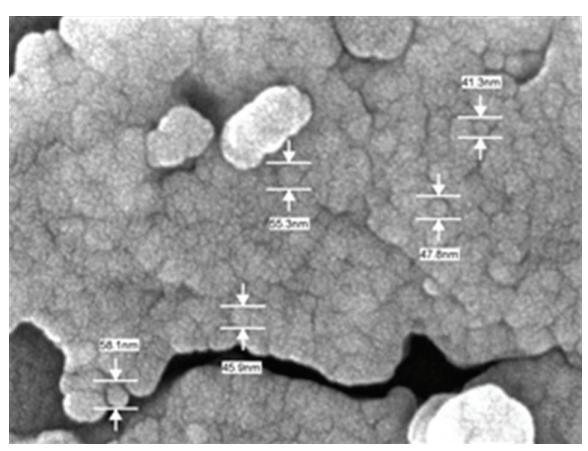

(b) Sample B

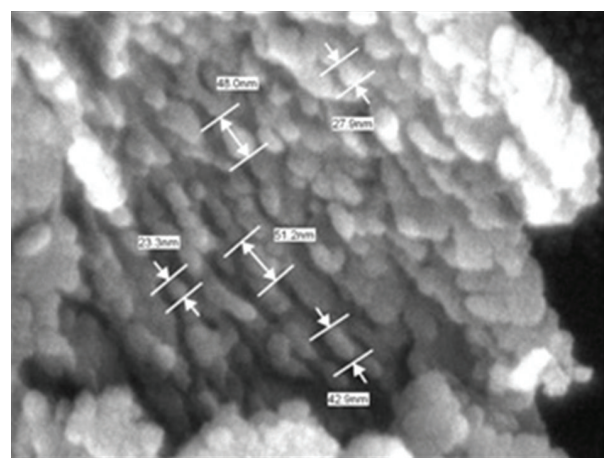

(c) Sample C

Figure 4: FESEM images of nanostructured a-C thin films at (a) $400^{\circ} \mathrm{C}$, (b) $450^{\circ} \mathrm{C}$, and (c) $500^{\circ} \mathrm{C}$.

The surface morphology images were captured by the JEOL JSM-7600F field emission scanning electron microscope (FESEM) at $100 \mathrm{kx}$ magnification, $10 \mathrm{kV}$ electron high tension (EHT). Figures 4(a), 4(b), and 4(c) represent the FESEM images for sample A, B, and C. The samples have the small average grain size, which was approximately $\sim 50 \mathrm{~nm}$. For particles with the size of less than $100 \mathrm{~nm}$, it was said to have the nanostructured sized particles. For sample A, the image was really in amorphous nature, since no sharp images were determined. However, we still manage to obtain the small particle size of sample A. When deposition temperature increased at sample B, more regular pattern was exhibited; however, the particles seem to be agglomerated. Next at sample C, clear shapes were seen, still with the amorphous behavior. At sample $\mathrm{C}$, the particles were becoming more cylindri$\mathrm{cal}$ in shapes and differed from the previous samples. With increasing deposition temperature, the particle seems to migrate and perform more accurate shapes. The film's surface morphology were influenced by the charge carrier mobility and absorption spectra [26]. Thus, the connection between the electrical and optical behavior towards the surface morphology was observed.

The presentation of nanostructured material in solar energy conversion was extensively studied by Oelhafen and Schüler [27], where it describes on the dye sensitized solar cell in nanoscale form and the application of nanostructured a-C: $\mathrm{H} / \mathrm{Au}$ in the solar cell. Nanostructured thin films such as the nanostructured $\mathrm{a}-\mathrm{C}$ has been studied in this paper plays the role as optically selective absorber layer for the carbonbased solar cell application. For the nanostructured material, the optical absorption path is much larger [28]; thus when light strikes the thin film, the absorption coefficient will greatly increase. Secondly, the nanostructured behavior of the thin film will enable the absorber layer to be designed very thin; thus the light-generated electrons and holes will only have to travel over much shorter path, and thus the recombination losses are greatly reduced [29]. Thirdly, since the size of the nanoparticles is very small and in nanoscale, the energy band gap can be tailored by varying the size of the nanoparticles. Thus more designs of the absorber layers in the solar cell can be done [28]. Those factors have become the fundamental properties of the nanostructured materials to be studied for numerous potential application especially in photovoltaic field [30, 31].

Deposition of nanostructured a-C on $\mathrm{n}-\mathrm{Si}$ substrate is needed to determine the suitability of nanostructured a-C to create a heterojunction structure between $\mathrm{p}-\mathrm{n}$ junctions. By using the AACVD method, the nanostructured a-C which is naturally $\mathrm{p}$ type was fabricated on $\mathrm{n}$-Si substrate, and the characteristics were measured by a Bukoh Keiki CEP2000 solar simulator system as shown in Figures 5(a) and 5(b). Gold $(\mathrm{Au})$ as the electrode in $\mathrm{Au} / \mathrm{p}-\mathrm{C} / \mathrm{n}-\mathrm{Si} / \mathrm{Au}$ was deposited by using sputter coater system (thickness $60 \mathrm{~nm}$ at bottom and $15 \mathrm{~nm}$ at top). The contacts served as an active area for the cells of configuration $\mathrm{Au} / \mathrm{p}-\mathrm{C} / \mathrm{n}-\mathrm{Si} / \mathrm{Au}$.

By varying the deposition temperature, the fabricated solar cell was characterized in dark and under illumination conditions. In a dark surrounding, the cell shows very slight rectifying characteristic (Figure 5(a)). However, all the samples indicate $0 \%$ for fill factor (FF) value. Thus, the solar 

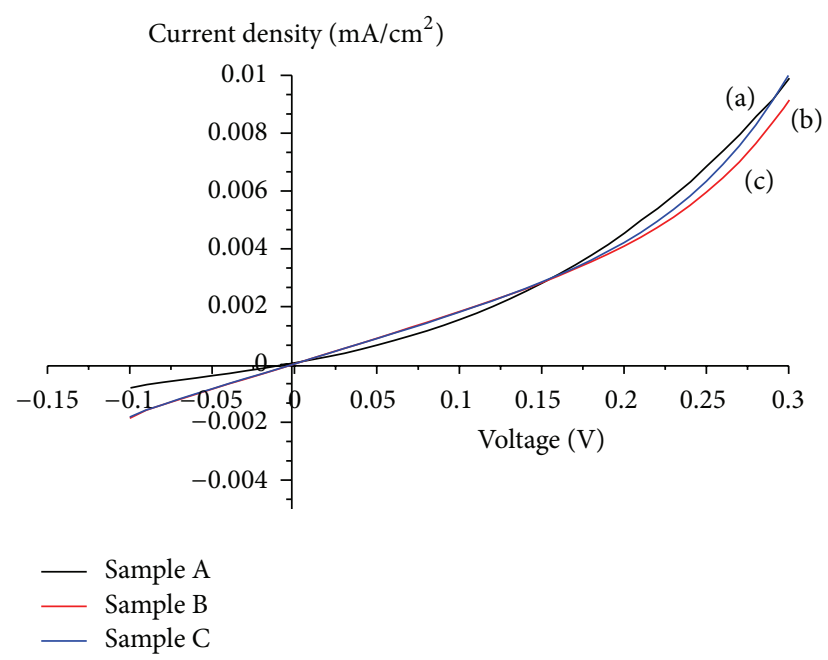

(a)

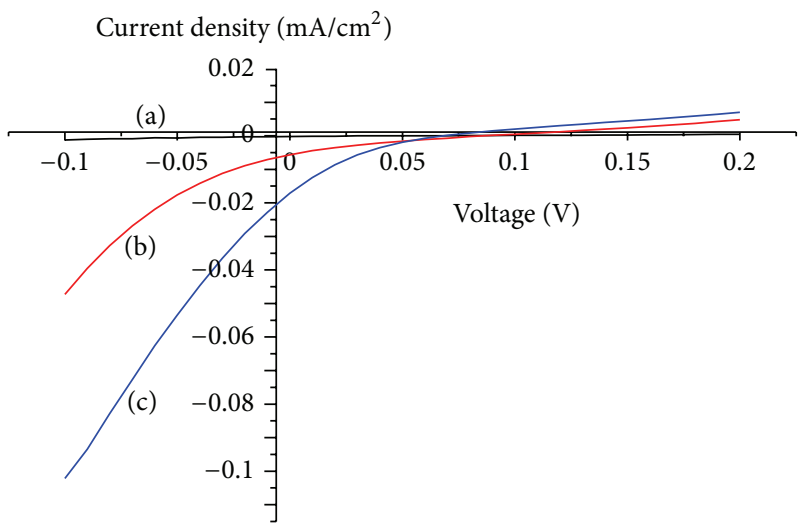

Sample A
— Sample B
Sample C

(b)

Figure 5: $J-V$ characteristics of the $\mathrm{Au} / \mathrm{p}-\mathrm{C} / \mathrm{n}-\mathrm{Si} / \mathrm{Au}$ photovoltaic cells (a) in dark and (b) under illumination.

cell efficiency $\eta=\left(V_{\mathrm{oc}}\right)\left(J_{\mathrm{sc}}\right)(\mathrm{FF}) /\left(J_{\mathrm{ph}}\right)$ [32] where $\eta$ is the overall efficiency, $J_{\mathrm{sc}}$ is the short circuit current density, $V_{\mathrm{oc}}$ is the open circuit voltage, and $J_{\mathrm{ph}}$ is the incident photon flux which was determined to be $0 \%$ for all samples. However, when being illuminated under AM 1.5 SUN condition $\left(100 \mathrm{~mW} / \mathrm{cm}^{2}, 25^{\circ} \mathrm{C}\right)$ a rectifying curve was obtained as in Figure 5(b). Thus these rectifying curves signify a heterojunction between the p-type nanostructured a-C film and the n-Si substrate $[33,34]$.

The fabricated solar cell with the configuration of $\mathrm{Au} / \mathrm{p}$ $\mathrm{C} / \mathrm{n}$-Si/Au achieved efficiency $(\eta)$ of $1.72 \times 10^{-4} \%$ for sample C, $1.24 \times 10^{-4} \%$ for sample B, and $0.03 \times 10^{-4} \%$ for sample A. Open circuit voltage $V_{\text {oc }}$ and short circuit current density $J_{\text {sc }}$ vary from 0.06 to $0.13 \mathrm{~V}$ and from 0.000078 to $0.02 \mathrm{~mA} / \mathrm{cm}^{2}$, respectively. Details on the solar cell performance were tabulated in Table 1. Obviously there was a trend in efficiency value which could be observed from the graph in Figures 5(a) and 5(b) since the efficiency increased along with the deposition
TABLE 1: Photovoltaic device parameters for Au/p-C/n-Si/Au.

\begin{tabular}{lcccc}
\hline Sample & $\eta(\%)$ & $V_{\text {oc }}(\mathrm{V})$ & $J_{\text {sc }}\left(\mathrm{mA} / \mathrm{cm}^{2}\right)$ & FF \\
\hline A & 0.000003 & 0.134561 & 0.000078 & 0.365008 \\
B & 0.000124 & 0.063751 & 0.012990 & 0.150137 \\
C & 0.000172 & 0.068410 & 0.017141 & 0.147059 \\
\hline
\end{tabular}

temperature (thickness increased as deposition temperature increased). The efficiency is still low compared to other reported carbon solar cell with same configuration [35-37], but the value is comparable as reported by Yap et al. [24] and Umeno and Adhikary [38]. Thus the presence of efficiency value clarified the tendency of using the nanostructured a-C by AACVD as the absorber layer in carbon based solar cell.

The mechanism of electron movement in $\mathrm{Au} / \mathrm{p}-\mathrm{C} / \mathrm{n}$ $\mathrm{Si} / \mathrm{Au}$ will be explained. The $\mathrm{n}-\mathrm{Si}$ becomes a depletion layer by performing $\mathrm{p}-\mathrm{n}$ abrupt junction, and the nanostructured a-C film plays the role of electron-transporter and holes blocking film. Few photons emitted from the xenon lamp AM1.5 illumination $\left(100 \mathrm{~mW} / \mathrm{cm}^{2}, 25^{\circ} \mathrm{C}\right)$ were absorbed by the nanostructured a-C thin film, and many photons were absorbed by the $\mathrm{n}-\mathrm{Si}$ surface layer, thus generates the electron-hole pair. The Au will then receive the electrons drifted from the nanostructured a-C film, where at first the electrons were excited in conduction band of $\mathrm{n}-\mathrm{Si}$ and were being transferred to the nanostructured a-C films. The holes excited in the valence band of $n$-Si will flow back to the $n$ Si substrate and drift to Au contact. The generation of the electron-hole pair as well as the electrons and holes drifting creates the current with high efficiency. The $\mathrm{sp}^{2}$ carbon bonding inside the nanostructured $\mathrm{a}-\mathrm{C}$ film contributes to the transport of electrons by hopping to the $\mathrm{Au}$ contact $[34,39]$ and acts as the holes barrier to prevent the holes injection. As deposition temperature increased, the thickness increased and the resistivity decreased $\left(\mathrm{sp}^{2}\right.$ increase). Thus the photogenerated carriers could be easily transported to the $\mathrm{Au}$ electrode and lead to increasing efficiency as deposition temperature increased [34].

\section{Conclusion}

Nanostructured amorphous carbon thin films with thickness $\sim 42-67 \mathrm{~nm}$ were deposited on glass and $\mathrm{n}$-Si substrates by utilizing the aerosol-assisted chemical vapor deposition (AACVD) method using camphor oil as a precursor. At higher deposition temperature, nanostructured a-C sample obtained higher conductivity due to the fact that when thickness increases, the carrier concentration and carrier mobility will increase along thus leading to higher conductivity. Also, as temperature increases the intensity of $\pi^{*}$ region increases, specifying the promotion of $\mathrm{sp}^{2}$ bonding due to increase in graphitic order thus contributing to higher conductivity. High transmittance (>85\%) and absorption coefficient, $\alpha$ in the range of $\sim 10^{4} \mathrm{~cm}^{-1}$, were determined. From Tauc's plot, optical band gap $\left(E_{g}\right)$ was determined, and $E_{g}$ decreases as deposition temperature increases $(1.2 \mathrm{eV}, 1.0 \mathrm{eV}, 0.7 \mathrm{eV})$.

On the other hand, the nanostructured behavior of the nanostructured a-C thin films by AACVD was confirmed by 
using the FESEM images. The suitability of using the nanostructured material for the carbon-based solar cell application was also discussed. To prove the suitability for nanostructured a-C deposited by AACVD for carbon-based solar cell application, the device was fabricated with the configuration of $\mathrm{Au} / \mathrm{p}-\mathrm{C} / \mathrm{n}-\mathrm{Si} / \mathrm{Au}$. The $\mathrm{Au} / \mathrm{p}-\mathrm{C} / \mathrm{n}-\mathrm{Si} / \mathrm{Au}$ photovoltaic cells under the light illumination AM 1.5 SUN condition $\left(100 \mathrm{~mW} / \mathrm{cm}^{2}, 25^{\circ} \mathrm{C}\right)$ from solar simulator system indicate the rectifying curve for all the samples. The rectifying curves signify the heterojunction between the p-type nanostructured $\mathrm{a}-\mathrm{C}$ film and the $\mathrm{n}-\mathrm{Si}$ substrate and designate the generation of electron-hole pair of the samples under illumination. As deposition temperature increased, the resistivity decreased ( $\mathrm{sp}^{2}$ increase), and thus the photogenerated carriers could be easily transported to the Au electrode and lead to increasing efficiency as deposition temperature increased.

\section{References}

[1] Y. Tang, Y. S. Li, Q. Yang, and A. Hirose, "Characterization of hydrogenated amorphous carbon thin films by end-Hall ion beam deposition," Applied Surface Science, vol. 257, no. 10, pp. 4699-4705, 2011.

[2] J. Podder, M. Rusop, T. Soga, and T. Jimbo, "Boron doped amorphous carbon thin films grown by r.f. PECVD under different partial pressure," Diamond and Related Materials, vol. 14, no. 11-12, pp. 1799-1804, 2005.

[3] S. M. Mominuzzaman, M. Rusop, T. Soga, T. Jimbo, and M. Umeno, "Nitrogen doping in camphoric carbon films and its application to photovoltaic cell," Solar Energy Materials and Solar Cells, vol. 90, no. 18-19, pp. 3238-3243, 2006.

[4] K. Abe and O. Eryu, "Optical properties of amorphous carbon films implanted with nitrogen," Nuclear Instruments and Methods in Physics Research B, vol. 242, no. 1-2, pp. 637-639, 2006.

[5] H. Zhu, J. Wei, K. Wang, and D. Wu, "Applications of carbon materials in photovoltaic solar cells," Solar Energy Materials and Solar Cells, vol. 93, no. 9, pp. 1461-1470, 2009.

[6] N. D. Baydoğan, "Evaluation of optical properties of the amorphous carbon film on fused silica," Materials Science and Engineering $B$, vol. 107, no. 1, pp. 70-77, 2004.

[7] O. S. Panwar, M. A. Khan, B. S. Satyanarayana, S. Kumar, and Ishpal, "Properties of boron and phosphorous incorporated tetrahedral amorphous carbon films grown using filtered cathodic vacuum arc process," Applied Surface Science, vol. 256, no. 13, pp. 4383-4390, 2010.

[8] X. Hou and K. L. Choy, "Processing and applications of aerosol-assisted chemical vapor deposition," Chemical Vapor Deposition, vol. 12, no. 10, pp. 583-596, 2006.

[9] M. G. Nolan, J. A. Hamilton, S. Obrien et al., "The characterisation of aerosol assisted CVD conducting, photocatalytic indium doped zinc oxide films," Journal of Photochemistry and Photobiology A, vol. 219, no. 1, pp. 10-15, 2011.

[10] C. E. Knapp, G. Hyett, I. P. Parkin, and C. J. Carmalt, "Aerosolassisted chemical vapor deposition of transparent conductive galliumâ "Indiumâ" oxide films," Chemistry of Materials, vol. 23, pp. 1719-1726, 2011.

[11] A. Salaün, J. A. Hamilton, D. Iacopino et al., "The incorporation of preformed metal nanoparticles in zinc oxide thin films using aerosol assisted chemical vapour deposition," Thin Solid Films, vol. 518, no. 23, pp. 6921-6926, 2010.
[12] M. Sharon, D. Pradhan, Y. Ando, and X. Zhao, "Electrical and optical properties of semiconducting camphoric carbon films," Current Applied Physics, vol. 2, no. 6, pp. 445-450, 2002.

[13] C. W. Tan, S. Maziar, E. H. T. Teo, and B. K. Tay, "Microstructure and through-film electrical characteristics of vertically aligned amorphous carbon films," Diamond and Related Materials, vol. 20, no. 3, pp. 290-293, 2011.

[14] N. Dwivedi, S. Kumar, H. K. Malik, Govind, C. M. S. Rauthan, and O. S. Panwar, "Correlation of sp3 and sp2 fraction of carbon with electrical, optical and nano-mechanical properties of argon-diluted diamond-like carbon films," Applied Surface Science, vol. 257, no. 15, pp. 6804-6810, 2011.

[15] F. Alibart, O. Durand Drouhin, M. Lejeune, M. Benlahsen, S. E. Rodil, and E. Camps, "Evolution of the opto-electronic properties of amorphous carbon films as a function of nitrogen incorporation," Diamond and Related Materials, vol. 17, no. 6, pp. 925-930, 2008.

[16] M. Ben Karoui, R. Gharbi, N. Elzayed, M. Fathallah, and E. Tresso, "Microstructural and electrical properties of amorphous carbon nitride," Physics Procedia, vol. 2, pp. 873-879, 2009.

[17] L. Y. Huang and L. Meng, "Effects of film thickness on microstructure and electrical properties of the pyrite films," Materials Science and Engineering B, vol. 137, no. 1-3, pp. 310-314, 2007.

[18] J. L. Endrino, D. Horwat, A. Anders, J. Andersson, and R. Gago, "Impact of annealing on the conductivity of amorphous carbon films incorporating copper and gold nanoparticles deposited by pulsed dual cathodic arc," Plasma Processes and Polymers, vol. 6, no. 1, pp. S438-S443, 2009.

[19] T. Suemasu, T. Saito, K. Toh, A. Okada, and M. A. Khan, "Photoresponse properties of $\mathrm{BaSi}_{2}$ epitaxial films grown on the tunnel junction for high-efficiency thin-film solar cells," Thin Solid Films, vol. 519, pp. 8501-8504, 2011.

[20] K. S. Han, J. H. Shin, and H. Lee, "Enhanced transmittance of glass plates for solar cells using nano-imprint lithography," Solar Energy Materials and Solar Cells, vol. 94, no. 3, pp. 583-587, 2010.

[21] J. Yoo, J. Lee, S. Kim et al., "High transmittance and low resistive ZnO:Al films for thin film solar cells," Thin Solid Films, vol. 480481, pp. 213-217, 2005.

[22] L. Shen, Y. Xu, F. Meng, F. Li, S. Ruan, and W. Chen, "Semitransparent polymer solar cells using $\mathrm{V}_{2} \mathrm{O}_{5} / \mathrm{Ag} / \mathrm{V}_{2} \mathrm{O}_{5}$ as transparent anodes," Organic Electronics, vol. 12, no. 7, pp. 1223-1226, 2011.

[23] S. Adhikari, H. R. Aryal, D. C. Ghimire, G. Kalita, and M. Umeno, "Optical band gap of nitrogenated amorphous carbon thin films synthesized by microwave surface wave plasma CVD," Diamond and Related Materials, vol. 17, no. 7-10, pp. 1666-1668, 2008.

[24] S. S. Yap, H. K. Yow, and T. Y. Tou, "Amorphous carbon-silicon heterojunctions by pulsed Nd:YAG laser deposition," Thin Solid Films, vol. 517, no. 18, pp. 5569-5572, 2009.

[25] S. Adhikari, D. C. Ghimire, H. R. Aryal, S. Adhikary, H. Uchida, and M. Umeno, "Boron-doped hydrogenated amorphous carbon films grown by surface-wave mode microwave plasma chemical vapor deposition," Diamond and Related Materials, vol. 15, no. 11-12, pp. 1909-1912, 2006.

[26] Z. Zhuo, F. Zhang, J. Wang et al., "Efficiency improvement of polymer solar cells by iodine doping," Solid-State Electronics, vol. 63, pp. 83-88.

[27] P. Oelhafen and A. Schüler, "Nanostructured materials for solar energy conversion," Solar Energy, vol. 79, no. 2, pp. 110-121, 2005.

[28] R. S. Singh, V. K. Rangari, S. Sanagapalli, V. Jayaraman, S. Mahendra, and V. P. Singh, "Nano-structured CdTe, CdS and 
$\mathrm{TiO}_{2}$ for thin film solar cell applications," Solar Energy Materials and Solar Cells, vol. 82, no. 1-2, pp. 315-330, 2004.

[29] A. Belaidi, R. Bayón, L. Dloczik, K. Ernst, M. C. Lux-Steiner, and R. Könenkamp, "Comparison of different thin film absorbers used in eta-solar cells," Thin Solid Films, vol. 431-432, pp. 488491, 2003.

[30] B. Bhushan, "Introduction to Nanotechnology," in Springer Handbook of Nanotechnology, pp. 1-6, Springer, Berlin, Germany, 2004.

[31] M. Steinhart, "Introduction to Nanotechnology", in Angewandte Chemie, V. C. P. Poole Jr. and F. J. Owens, Eds., vol. 116, pp. 22462247, 2004.

[32] C. Z. Kim, H. Kim, K. M. Song et al., "Enhanced efficiency in GaInP/GaAs tandem solar cells using carbon doped GaAs in tunnel junction," Microelectronic Engineering, vol. 87, no. 4, pp. 677-681, 2010.

[33] M. A. Green, "Photovoltaic principles," Physica E, vol. 14, no. 1-2, pp. 11-17, 2002.

[34] H. Kinoshita, M. Kiyama, and H. Suzuki, "Supermagnetron plasma CVD of highly effective a-CNx:H electron-transport and hole-blocking films suited to $\mathrm{Au} / \mathrm{a}-\mathrm{CNx}: \mathrm{H} / \mathrm{p}-\mathrm{Si}$ photovoltaic cells," Thin Solid Films, vol. 517, no. 14, pp. 4218-4221, 2009.

[35] Z. Q. Ma and B. X. Liu, "Boron-doped diamond-like amorphous carbon as photovoltaic films in solar cell," Solar Energy Materials and Solar Cells, vol. 69, no. 4, pp. 339-344, 2001.

[36] H. A. Yu, Y. Kaneko, S. Yoshimura, and S. Otani, "Photovoltaic cell of carbonaceous film/n-type silicon," Applied Physics Letters, vol. 68, no. 4, pp. 547-549, 1996.

[37] M. Rusop, A. M. M. Omer, S. Adhikari et al., "Photoconductivity effects of nitrogenated carbonaceous films grown on various types of substrates by surface wave microwave plasma CVD," Solar Energy Materials and Solar Cells, vol. 90, no. 3, pp. 301-307, 2006.

[38] M. Umeno and S. Adhikary, "Diamond-like carbon thin films by microwave surface-wave plasma CVD aimed for the application of photovoltaic solar cells," Diamond and Related Materials, vol. 14, no. 11-12, pp. 1973-1979, 2005.

[39] K. Akimoto, S. Ishizuka, M. Yanagita, Y. Nawa, G. K. Paul, and T. Sakurai, "Thin film deposition of $\mathrm{Cu}_{2} \mathrm{O}$ and application for solar cells," Solar Energy, vol. 80, no. 6, pp. 715-722, 2006. 

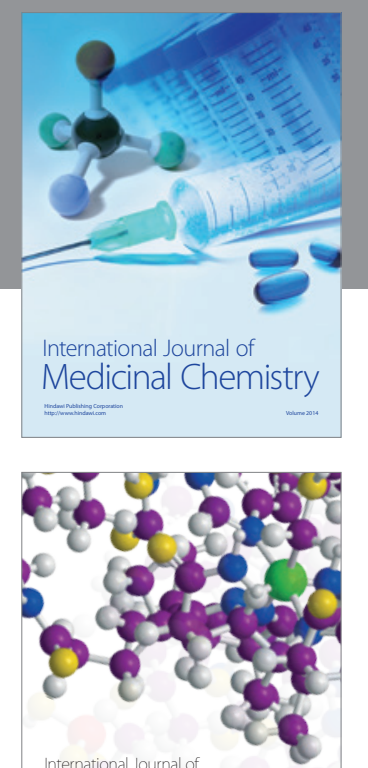

\section{Carbohydrate} Chemistry

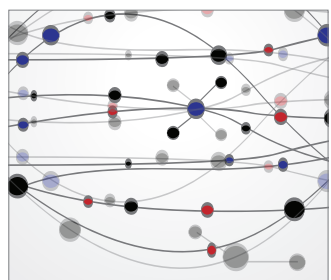

The Scientific World Journal
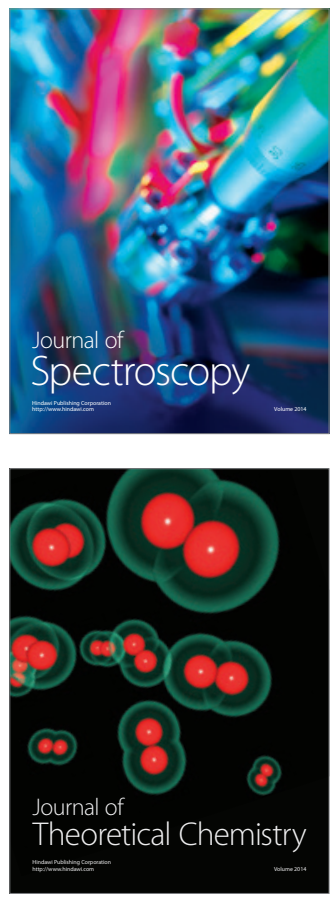
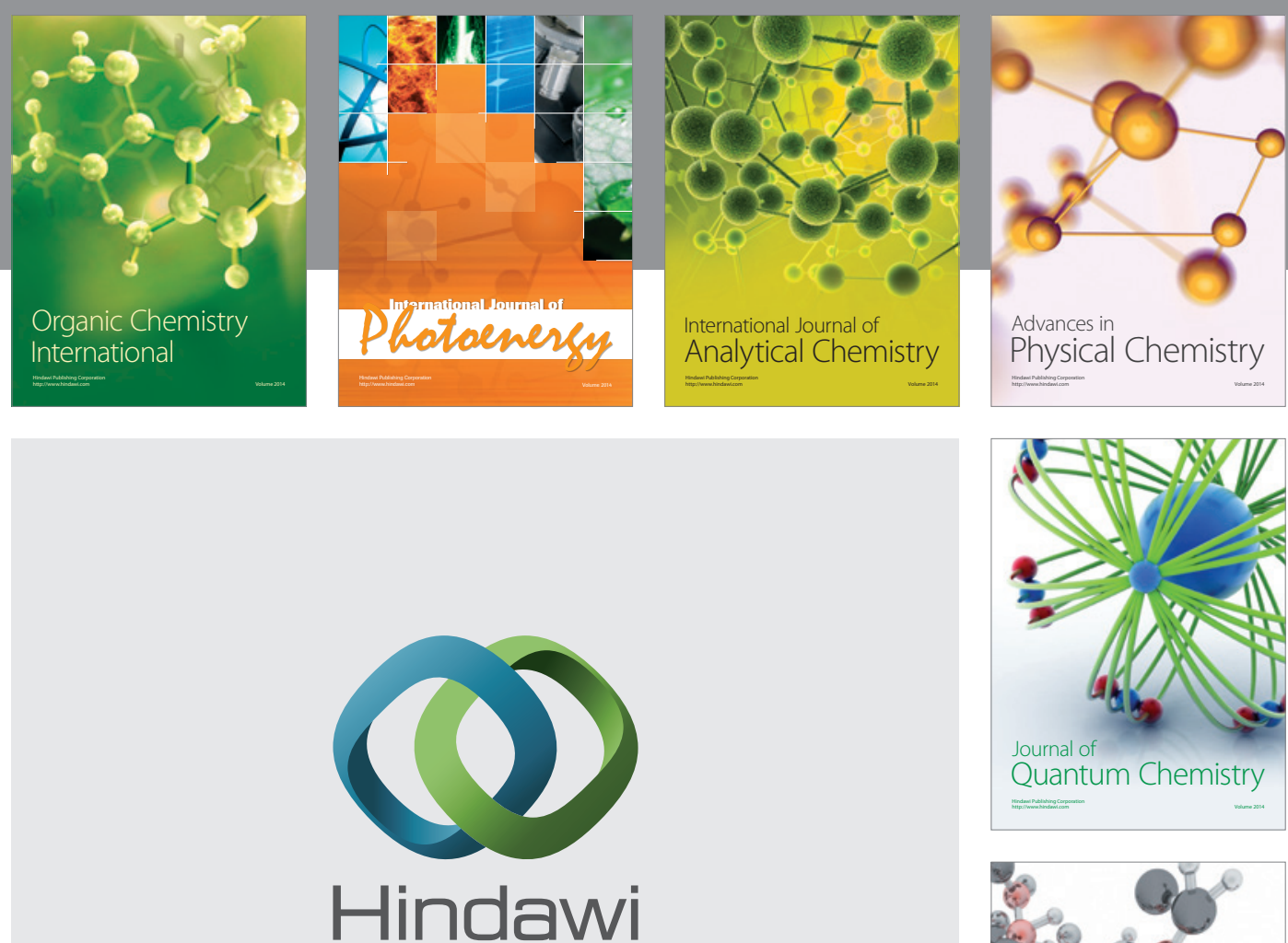

Submit your manuscripts at

http://www.hindawi.com

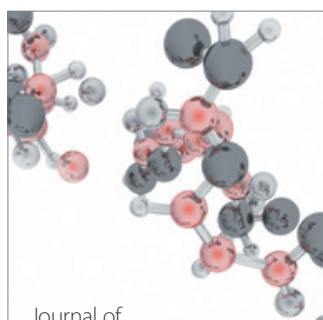

Analytical Methods

in Chemistry

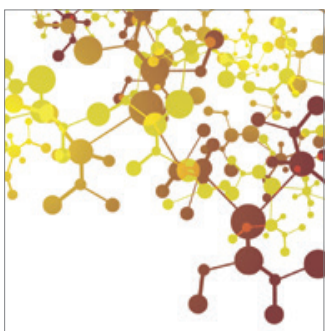

Journal of

Applied Chemistry

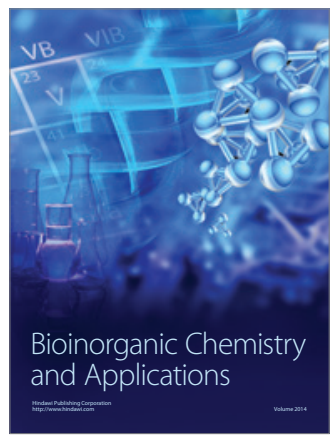

Inorganic Chemistry
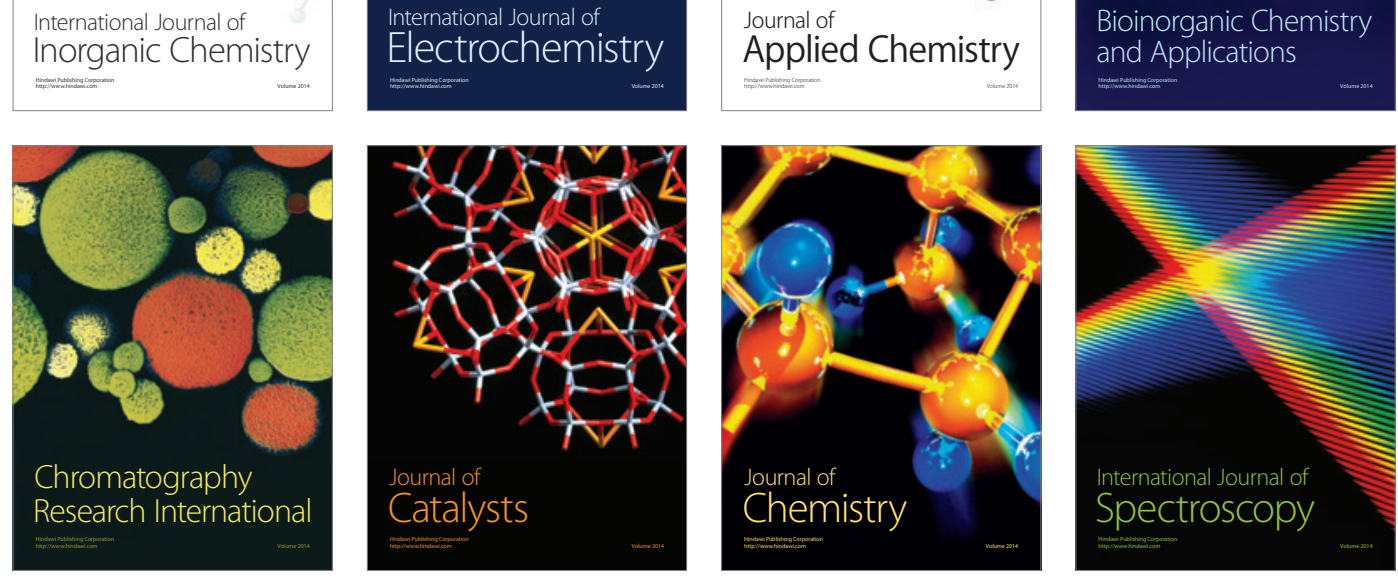